\title{
PUBLIC EDUCATION IN FOREST FIRE PREVENTION ${ }^{1}$ \\ BY W. S. MACDONNElL

\author{
Canadian Forestry Association of Ontario, Toronto, Ontario
}

What is our conception of Public Education in Forest Fire Prevention. Probably each of us has his own idea on this subject, and a dictionary will not help much in securing precise agreement. It would, therefore, be unwise to speak on the problems involved without first defining the process of public education.

Public education in forest fire prevention is that form of indirect control or pre-suppression, which expresses itself by establishing the right attitude of mind in persons who may be responsible for the starting of forest fires As has been demonstrated in Europe, indirect control will ultimately succeed, but only by persistent effort. It can create a public attitude which will guarantee that very few fires will start except those from malicious intent, unavoidable accidents or natural causes. Only when this result is achieved can the urgent task of public education be considered as successfully undertaken.

My intention is to confine remarks on this subject to problems which apply in the Province of Ontario. Within this province there are two different areas which require different educational treatment.

These are:

1. That area lying within the Government Administered Fire District, mainly composed of Crown Lands, and known generally as Northern Ontario.

2. That area outside the Fire District, consisting almost entirely of private ownership, referred to in general terms as Southern Ontario.

During the 18 years prior to 1948 the average number of acres burned per year was 240,434 . In 1948 the area burned was 1,017,389 acres. This disastrous year increased the average to 317,637 acres per year; an increase of approximately one-third on the average for the last 19 years. In 1948 two large fires in the Mississaugi Provincial Forest alone burned 645,340 acres, all under license to one company. This certainly indicates the urgent need for a modern adequate fire prevention campaign to inform the public of the serious consequences of forest fire in this province. Individual members of industry should realize from this example that one critical fire may put a local industry out of business. In so doing it can seriously disrupt the economic structure for many years.

Fire records of the past decade show that the greatest number of fires occur during the months of July and August when tourist travel is at its peak. It is, therefore, within this period that we need the most intensive effort in fire prevention. Critical forest fires, however, have been experienced during the spring and fall hazard periods, and it would be fallacy to think that a serious fire prevention campaign is not needed during these periods. Approximately 20 per cent of forest fires occurring in the Government Administrational

1. Paper presented at the 1919 annual meeting of the Canadian Societs of Forest Engineers, Toronto, October $24-26,1949$. 
Fire District have been caused by lightning. The remaining 80 per cent were started through human agencies and in almost all cases were preventable, had reasonable precautions been taken.

A major point in determining the medium to use in teaching forest fire prevention is the means of evaluating its impact on the people in comparison with other media. You see before you two examples-one is an illuminated sign, the other a set of posters. At this moment which has the greater impact. Unquestionably the illuminated sign because it is animated. Your curiosity and attention are centred on it. Your mind is conditioned to receive its message. Make no mistake, however-posters also have their impact and reference is made to them later. The problem is to measure scientifically the stimulus of various media under given circumstances and apply only the most effective for each field. This is the high and hidden cost of effective fire prevention education.

Let us now consider for a moment what the objectives of a forest fire prevention program might be. They might be summarized as follows:

1. To cultivate a protective community interest in our forests.

2. To correct the beliefs that forests are inexhaustible.

3. To explode the idea that reforestation can compensate for fire loss.

4. To develop an understanding of fire hazards and the precautions necessary.

5. To demonstrate the significance of the forest industry in the economy of the province.

The main channels through which these objectives can be attained are:

1. Motion pictures and lecture tours by informed persons.

2. Co-operation of radio, press, public institutions and the industry in consistently placing information before the public.

3. Conservation courses prepared for teachers so that they may competently teach school children proper conservation practice, including fire precautions.

4. Development of conservation group movements, 4-H Clubs, Junior Forest Wardens, Boy Scouts, Hunting and Fishing groups, etc.

5. Travel permits issued for forest travel during hazard seasons.

6. Through fiction and non-fiction to develop an interest in our forests for recreational purposes.

How can fire prevention be taught in Northern Ontario? There is the incidence of fire caused by employees of industry engaged in harvesting the forest. Undoubtedly matches and tailor made cigarettes have been the cause of many forest fires in the past. All companies should encourage their men, as some do, to use lighters and hand-rolled cigarettes, or a pipe, for these are known to be less hazardous. "No Smoking" in the forest during fire hazard periods should be enforced except during periods of rest. Fire Rangers should visit lumber camps regularly to show fire prevention films and to give short talks on fire prevention. Posters should be placed throughout company limits descriptive of fire regulations. These should be available in the quantities needed from a central source at a minimum cost. A Fire Prevention Committee should be formed of company representatives, fire rangers, and 
conservation officials to meet regularly during the fire season to discuss local problems. Companies should sponsor forest fire messages in newspapers and radio spot announcements for their areas during this period. With each pay cheque there should be a company message to the individual worker on the forest fire problem and its direct bearing on his pay cheque. Companies should request the assistance of the Conservation Association formed for the purpose of teaching fire prevention and forest conservation in the province.

A word about the Ontario government services. There is an Information and Education Branch within the Department of Lands and Forests, and although of fairly recent origin, it has made excellent progress. The Department should be commended for this start in public relations and education. They should be urged to continue and enlarge its scope. In the past there has been no difficulty in obtaining the money necessary to fight fires, but it has been impossible to obtain adequate funds for fire prevention. While fires must be fought it is regrettable that such a large portion of public funds are spent in fighting fires rather than in preventing fires. What is there to show, for example, for the million or more dollars it cost the public to fight the two Mississaugi fires last year-only a thousand square miles of devastated timberland from which two million board feet of lumber have been salvaged. Nothing more of consequence will be harvested there in our lifetime. Is it not conceivable that this money, if spent in educating for forest fire prevention, might have prevented these and many more of the 1400 odd fires that occur annually in this province? Governments today are stressing fire suppression. Is this not putting the cart before the horse? More stress on fire prevention would mean less work for the fire suppression organization. A badly burned area becomes a non-productive area and cannot be harvested again for fifty years. No amount of money or effort can replace it once it is gone. Forest fire prevention is the key to forest fire protection.

Apart from the incidence of fire caused by those in industry there is great danger of fire from tourists. Educating the public to exercise great caution with fire in the woods is a long term proposition. In the meantime certain restrictive measures would help to contain these fires. All infringements of the fire laws should be prosecuted vigorously. Convictions for an offence should be given wide publicity. This type of publicity is invaluable in acting as a deterrent to public carelessness with fire. It has been learned from a number of informed sources during this past year that permits to enter forest areas during the fire hazard season have been a potent instrument in reducing the number of fires. These bring the seriousness of fire forcibly to the attention of the public, and those concerned know they can be traced and prosecuted if they are careless with fire while travelling in the forest.

Tourist camp operators in the forest areas should be required to bear a responsibility equal to that of other forest industries in fire prevention. Their guides should be licensed only if they adhere strictly to the fire laws. This would emphasize to the vacationing public the importance of forest fire prevention. Another important tool that should be developed is the use of fire prevention posters in bold colours, marking the forest trail and assuring the traveller he is on the proper route. Many men when travelling an un- 
familiar trail have paused and thoroughly read the written directions on a poster. Fire posters of this nature would be looked for by the public when in the forest. They should be of uniform size and striking colour, and the directions as to how to get from one location to another could be printed in by the fire ranger when placing them on the trail.

What are the main problems of fire prevention education in the area outside the fire district-that is, the area of private ownership. Last year private woodlot owners in Ontario sold 625,000 cords of wood worth 10 million dollars. Where forest lands and pasture lands are contiguous, grass fires cause continual encroachment on the forest area. Dead grass is a flash fuel that constantly endangers private woodlands. Last year in the Eastern Counties of Ontario 5,000 acres of forest were reported burnt, but no one knows how many fires there are each year, nor how many acres are burned over. There is no organized procedure in reporting fires south of the government protected area of Crown Land Forests. Each year houses, barns and woodlots are continually in danger and in some cases are destroyed as a result of grass or bush fires being set to clear the land. Public education in these areas is badly needed. What can be done to prevent the rapid deterioration of these lands now seriously lacking in forest cover? Here is a field of work that is a challenge to any conservation organization.

A well-known conservation leader recently said, "One of the hardest things to give away is free education." We must teach fire prevention in such a manner that the public will want more and more of this teaching. Approaches might be made from the following psychological angles:

1. Show the public that they have something to lose individually.

2. Prove that they are going to lose it unless they do something about it.

3. Show them how a small amount of their time spent in community work would help to prevent loss.

These approaches could be made-

1. By social organizations undertaking fire prevention as an extra-curricular activity.

2. By repetitive advertising in newspapers, periodicals and radio.

3. By a public relations campaign with lecture tours and moving pictures.

4. By teaching conservation in the schools and churches.

5. By a placard campaign.

The best progress is made over the widest area by having people work at something together. The formation of conservation committees representing local areas in a larger overall group setup provides such an opportunity. Then, great benefits are derived from youth groups, such as $4-\mathrm{H}$ Clubs and Junior Forest Warden organizations. In Quebec there are approximately 8,000 members of these organizations. Since it is realized that for every 8 children the assistance of 3 adults is needed, fire prevention contests have been held, and there is a yearly congress or general assembly. Industrial firms of the area contribute prizes and financial support and a small membership fee is charged each member. Gradually the entire community becomes fire hazard conscious through such activity.

The church holds a most important place in our community life, our 
national welfare and our future as a nation. The voice from the pulpit wields a mighty influence. Forest fires can reduce to deplorable levels the scale of living in the afflicted community. Poor food, lack of clothing and inadequate shelter cause ill health, indolence, discouragement and low moral standards. Forest fires can bring about a drastic and suddenly reduced scale of living. Community welfare is one of the primary concerns of the church. This fact is demonstrated by the activity of the churches of Quebec in support of forest conservation. Herein lies an opportunity in Ontario for a program of public education in forest fire prevention in which the horizons are unlimited.

Another phase of public education in fire prevention can be accomplished through the enactment and enforcement of legislation that is uniform throughout an area. It is needed to guide and assist county officials in fighting fires in townships, outside the government administered fire protection area. Legislation should be enacted to authorize the appointment of a Fire Warden for each township. The Fire Warden should be empowered to hire men and equipment as needed to combat private woodland fires. A publicity campaign must inevitably follow to publicize the laws which have been enacted, and in this way the people of the area will become conscious of the fire hazard in their own community.

Every rural school should have a reforestation plot available on which their students can observe Arbour Day and plant a tree. Everyone connected with these efforts will develop a fire consciousness and take greater care of forested lands.

So far no reference has been made to the part the Canadian Forestry Association of Ontario is playing in the task of public education in forest fire prevention. This year fire prevention material and fire posters for display in their resorts were mailed to 4,500 resort operators. Ontario industry is being contacted for assistance and their responsibilities in this connection are being placed before them. Youth groups are being planned and community conservation groups are being assisted and stimulated. Branches of the organization are being established on a regional basis to further this work, which will only be limited by the support received from industry and the governments. Progress is difficult to measure in terms of a material nature, but the growth of membership, establishment of branch organizations within the province and the increase of youth work have been encouraging.

What can foresters do to assist public education in forest fire prevention? Many are members of the Canadian Forestry Association and thereby lend strength and support to its work. Foresters are needed as active participants in local conservation organizations. Foresters should write articles on forest fire prevention for local newspapers, and every forester should be officially designated Honorary Fire Warden. They should talk to school teachers on every occasion about conservation and strive to establish community forests in their area. The question is whether we shall participate in management or be the object of it. Public education requirements in forest fire prevention rate cabinet level recognition. 
Before progress can be made in bettering and securing our forest wealth we must accept the fact that forest fire prevention is a fundamental to any forest management plan. Therefore public education in forest fire prevention is of paramount importance at this time. The elimination of all man-made fires should be the final goal. To achieve this goal will require many years of concentrated effort in training and educating the forest using public. This calls for an expenditure in this field closely approximating that now spent in fire suppression. Industry and government alike must bear their full share of the financial burden to make this possible.

In the final analysis there are really only two problems confronting trained personnel in teaching fire prevention. They are specifically:

1. To determine the best methods of public education in forest fire prevention.

2. To obtain sufficient financial assistance to put these methods into effective use. 